\title{
Analisis Konsep Dokumentasi Keperawatan Sebagai Standar Penting Dalam Pelayanan Kesehatan Berkualitas
}

\section{Emyranda Samosir}

emyrandasamosir@gmail.com

\begin{abstract}
Dalam melakukan tugasnya perawat menempati posisi terdepan dari sistem pelayanan kesehatan di ruang rawat inap karena perawatlah yang secara terus-menerus selama 24 jam memantau perkembangan pasien dari sudut biopsikososiokultural dan spiritual. Dengan demikian peningkatan mutu pelayanan kesehatan serta keberhasilan pelayanan di rumah sakit sangat bergantung pada keberhasilan asuhan keperawatan yang dilakukan di rumah sakit tersebut. Mudah dipahami bila proses asuhan keperawatan tidak dilaksanakan dengan baik akan menyebabkan mutu pelayanan keperawatan menjadi kurang baik pula dan dengan demikian mutu pelayanan kesehatan rumah sakit secara keseluruhan menjadi tidak memuaskan klien. Berdasarkan Permenkes No. 269/Menkes/Per III/2008, dalam Bab I Ketentuan Umum Pasal 1 dinyatakan bahwa rekam medik adalah berkas yang berisikan catatan dan dokumen tentang identitas pasien, pemeriksaan, pengobatan, tindakan dan pelayanan lain yang telah diberikan kepada pasien. Tenaga kesehatan tertentu adalah tenaga kesehatan yang ikut memberikan pelayanan kesehatan secara langsung kepada pasien selain dokter dan dokter gigi. Dokumen adalah catatan dokter, dokter gigi, dan/atau tenaga kesehatan tertentu, laporan hasil pemeriksaan penunjang catatan observasi dan pengobatan harian dan semua rekaman, baik berupa foto radiologi, gambar pencitraan (imaging), dan rekaman elektro diagnostik. Jelas sekali dinyatakan bahwa rekam medik berisikan berkas catatan baik catatan medik (dokter) maupun catatan tenaga kesehatan lain yang berarti termasuk perawat dan atau catatan petugas kesehatan lain yang berkolaborasi melakukan upaya pelayanan kesehatan dimaksud. Berdasarkan hal di atas serta melihat pada tanggung jawab atas tugas profesi dengan segala risiko tanggung gugatnya di hadapan hukum, maka dokumentasi keperawatan memang benar diakui eksistensinya dan keabsahannya serta mempunyai kedudukan yang setara dengan dokumen medik lain.
\end{abstract}

Kata Kunci : Dokumentasi,Asuhan Keperawatan,Standar Pelayanan Kesehatan 


\section{Latar Belakang}

Keperawatan merupakan bagian integral yang tidak dapat dipisahkan dari upaya pelayanan kesehatan secara keseluruhan. Keperawatan adalah ilmu yang mempelajari sebab-sebab tidak terpenuhinya kebutuhan dasar manusia, serta upaya untuk memenuhi kebutuhan dasar tersebut sebagai respon pasien. Pelayanan keperawatan profesional yang berdasarkan ilmu pengetahuan mempunyai proses keperawatan yaitu suatu asuhan keperawatan sebagai metode ilmiah penyelesaian masalah keperawatan pasien untuk meningkatkan outcome pasien yang harus didokumentasikan (Aziz,2002).

\section{Pendokumentasian}

asuhan

keperawatan adalah kegiatan pencatatan, pelaporan dan pemeliharaan yang berkaitan dengan pengelolaan klien guna mempertahankan sejumlah fakta dari suatu kejadian dalam suatu waktu. UndangUndang RI Nomor 44 Tahun 2009 tentang Rumah Sakit Pasal 52 menyatakan bahwa setiap rumah sakit wajib melakukan pencatatan dan pelaporan semua penyelenggaraan kegiatan rumah sakit dalam bentuk sistim informasi manajemen berupa pencatatan, penyimpanan, pelaporan dan pemusnahan dalam waktu tertentu sesuai peraturan perundang-undangan.

Rumah sakit dalam pengelolaannya mempunyai pilar yang saling terkait satu sama lain yaitu: administrasi, manajemen berupa perencanaan setiap kegiatan, disiplin dari pelakunya, leadership dan kepemimpinan diri. Teori menyatakan "tulis apa yang ingin dilakukan, lakukan apa yang telah ditulis dan tulis apa yang telah dilakukan". Pelayanan yang diselenggarakan rumah sakit ada dua jenis yaitu pelayanan kesehatan dan administratif. Salah satu bentuk pelayanan kesehatan adalah pelayanan di poliklinik gigi berupa promotif, preventif, kuratif, rehabilitatif. Pelayanan administratif salah satunya adalah dokumentasi keperawatan yang berisi catatan keperawatan sebagai bukti pelaksanaan proses keperawatan dan catatan tanggapan/respon klien terhadap tindakan medis dan tindakan keperawatan yang telah dilaksanakan.

Pedokumentasian asuhan keperawatan yang tepat waktu, akurat dan lengkap tidak hanya penting untuk melindungi perawat tetapi penting juga untuk membantu pasien atau klien mendapat asuhan keperawatan yang lebih baik. 
Di Indonesia penelitian yang dilakukan oleh Dinas Kesehatan Mataram Provinsi Nusa Tenggara Barat tahun 2013 menunjukan bahwa $71,60 \%$ pengisian dokumentasi asuhan keperawatan belum lengkap.Ada banyak sekali faktor yang menyebabkan kurangnya kepedulian perawat dalam melakukan pendokumentasian dari setiap Tindakan yang telah mereka lakukan seperti memerlukan waktu yang cukup lama untuk mengisi form yang tersedia, membutuhkam biaya percetakan form yang cukup mahal, sering hilang atau terselip, memerlukan tempat penyimpanan yang luas dan menyulitkan pencarian kembali saat diperlukan. (Hadi, 2011). Disamping itu masih banyak perawat yang tidak tahu data apa yang harus dimasukkan dan bagaimana dokumentasi keperawatan yang benar.

\section{Tujuan}

Tujuan Pendokumentasiaan

keperawatan ialah :

- Sebagai sarana komunikasi.

- Sebagai tanggungjawab dan tanggunggugat.

- Sebagai informasi statistik.

- Sebagai sarana pendidikan.

- Sebagai sumber data penelitian.

- Sebagai jaminan kualitas pelayanan kesehatan.
- Sebagai sumber data perencanaan asuhan keperawatan berkelanjutan.

Tujuan kajian ini ialah untuk menganalisis konsep pendokumentasian yang benar sebagai standar penting dalam keperawtan yang berkualitas.

\section{Metode}

Rancangan penugasan kajian ini menggunakan literature review berdasarkan buku teks, buku referensi, jurnal, e-book (yang dipublikasikan 10 tahun terakhir) dan menggunakan dua belas sumber referensi dengan menganalisis, eksplorasi, dan kajian bebas sesuai dengan judul penugasan kajian ini

\section{Hasil}

American Nurses Association menekankan peran dokumentasi dengan pernyataan sebagai berikut: "Perawat bertanggungjawab untuk mengumpulkan data dan mengkaji tatus kesehatan klien, menentukan rencana asuhan keperawatan yang ditujukan untuk mencapai tujuan perawatan, mengevaluasi efektivitas asuhan keperawatan dalam mencapai tujuan perawatan dan mengkaji ulang serta merevisi kembali rencana asuhan 
keperawatan”. Dokumentasi keperawatan mempunyai makna penting bisa dilihat dari berbagai aspek

(Nursalam, 2009), antara lain: Hukum,Kualitaspelayanan,Komunikasi,Keu angan,pendidikan,akreditasi dan penelitian.

Tujuan dari komunikasi meiputi :

1.Komunikasi: catatan berfungsi sebagai sarana komunikasi bagi berbagai professional kesehatan yang berinteraksi dengan klien. Hal ini mencegah keterlambatan perawatan klien.

2. Merencanakan asuhan klien: setiap profesional menggunakan data dari catatan klien untuk merencanakan asuhan bagi klien tersebut.

3. Mengaudit institusi kesehatan: audit adalah tinjauan catatan klien untuk tujuan jaminan mutu. Untuk menentukan apakah institusi kesehatan tersebut memenuhi standar yang ditetapkan.

4. Penelitian: informasi yang tercantum dalam catatan dapat menjadi sumber data yang berharga untuk penelitian. Rencana terapi untuk sejumlah klien dengan masalah kesehatan yang sama dapat memberikan informasi yang bermanfaat dalam menangani klien lain.

5. Pendidikan: mahasiswa dalam disiplin kesehatan seringkali menggunakan catatan klien sebagai instrument pembelajaran. Catatan seringkali dapat memberikan pandangan komprehensif tentang klien, penyakit, strategi pengobatan yang efektif dan faktor yang mempengaruhi penyakit.

6. Penggantian pembayaran: dokumentasi juga membantu fasilitas menerima penggantian pembayaran dari pemerintah atau asuransi.

7. Dokumentasi sah: catatan klien adalah dokumentasi sah dan biasanya dapat diterima di pengadilan sebagai bukti.

8. Analisis layanan kesehatan: informasi dari catatan dapat membantu pembuat rencana perawatan kesehatan untukmeng identifikasi kebutuhan institusi. Catatan dapat digunakan untuk menetapkan biaya berbagai layanan dan mengidentifikasi layanan yang menghabiskan dana institusi dan layanan yang menghasilkan pendapatan.

Konsep pemodelan dokumentasi yang tepat ialah perawat ataau tenaga Kesehatan lainnya melakukakan dokumentasi pada setiap Tindakan yang berisikan informasi yang akurat,tepat dan dapat dipertanggung jawabkan. Dalam kerangka pemikiran kritis dan prosedur dokumentasi yang baik suatu prosedur tindakan dapat dilanjutkan atau dihilangkan, tergantung pada efektivitasnya. Dengan kata 
lain, apakah prosedur benar-benar meningkatkan, membantu atau membahayakan kesehatan klien. Ini hanyalah salah satu contoh bagaimana proses berpikir kritis digunakan dalam profesi keperawatan. Pendekatan ilmiah menggunakan pemikiran kritis membantu perawat mengembangkan praktik berbasis bukti.

\section{Pembahasan}

Keperawatan adalah pelayanan profesional berdasarkan ilmu dan kiat keperawatan, berbentuk pelayanan bio, psiko, sosio, dan spiritual komprehenshif yang ditujukan kepada individu, kelompok, dan masyarakat, baik sakit maupun sehat yang mencakup seluruh proses kehidupan manusia. Pelayanan keperawatan berupa bantuan, diberikan karena adanya kelemahan fisik dan mental, keterbatasan pengetahuan, dan kurangnya kemauan menuju kemampuan melaksanakan kegiatan sehari-hari.

Pelayanan profesional keperawatan memiliki metodologi yang menjamin tercapainya tujuan dengan optimal dan dapat dipertanggung-jawabkan secara moral dan hukum. Metodologi yang dimaksud adalah proses keperawatan. Proses keperawatan adalah suatu metode pemecahan masalah klien yang sistematis dan dilaksanakan sesuai dengan kaidah keperawatan. Oleh karena itu, proses keperawatan merupakan inti praktik keperawatan dan sekaligus sebagai isi pokok dokumentasi keperawatan. Penyelenggaraan proses keperawatan terdiri dari pengkajian, diagnosa, perencanaan, implementasi dan evaluasi. Semua tindakan tersebut harus didokumentasikan sebagai bukti penyelenggaraan proses keperawatan. Data klinis yang lengkap dan berkualitas dapat meningkatkan mutu layanan kesehatan. Keengganan klinisi menulis secara lengkap setiap proses penatalaksanaan medis merupakan kendala yang dihadapi

Dokumentasi secara umum merupakan suatu catatan otentik atau semua warkat asli yang dapat dibuktikan atau dijadikan bukti dalam persoalan hukum, sedangkan dokumentasi keperawatan merupakan bukti pencatatan dan pelaporan yang dimiliki perawat dalam melakukan catatan perawatan yang berguna untuk kepentingan klien, perawat, dan tim kesehatan dalam memberikan pelayanan kesehatan dengan dasar komunikasi yang akurat dan lengkap secara tertulis dengan tanggung jawab perawat (Hidayat, 2002).

Dokumentasi keperawatan terdiri dari 1) keterampilan berkomunikasi untuk pengumpulan data dan menciptakan hubungan baik antara perawat dan klien dalam pemecahan masalah klien. 2) 
dokumentasi proses keperawatan yang merupakan metode pemecahan masalah secara sistimatis sesuai kaidah keperawatan dan 3) standar dokumentasi dapat memberi informasi pernyataan kualitas dan kuantitas dokumentasi untuk memperkuat pola pendokumentasian keperawatan.

Menurut Serri (2010), tujuan dokumentasi keperawatan adalah:

$>$ Sebagai bukti kualitas asuhan keperawatan.

> Bukti legal dokumentasi sebagai pertanggungjawaban perawat kepada klien.

$>$ Menjadi sumber informasi terhadap perlindungan individu.

$>$ Sebagai bukti aplikasi standar praktik keperawatan.

> Sebagai sumber informasi statistik untuk standar dan riset keperawatan.

$>$ Dapat mengurangi biaya informasi terhadap pelayanan kesehatan.

$>$ Sumber informasi untuk data yang harus dimasukkan dalam dokumen keperawatan

yang lain sesuai dengan data yang dibutuhkan.

> Komunikasi konsep risiko asuhan keperawatan.

$>$ Informasi untuk peserta didik keperawatan.
Menjaga kerahasiaan informasi klien.

- Sebagai sumber data perencanaan pelayanan kesehatan di masa yang akan datang.

Dokumentasi

keperawatan mempunyai makna yang penting dalam berbagai aspek, yaitu aspek kualitas pelayanan karena pendokumentasian memberi kemudahan dalam memberikan pelayanan dan penyelesaian masalah klien sebagai acuan evaluasi untuk meningkatkan mutu pelayanan, aspek komunikasi dan sebagai sarana komunikasi antara perawat dengan klien atau keluarga, tenaga kesehatan lain sehingga dapat membentuk suatu koordinasi yang baik dan tidak terjadi duplikasi yang tidak efektif dan efisien, aspek hukum sebagai dokumen resmi dan bernilai hukum atau legalitas dalam sistem pelayanan keperawatan sehingga apabila terjadi suatu masalah hukum maka dokumentasi dapat dijadikan sebagai barang bukti di pengadilan, aspek pendidikan dan pelatihan dokumentasi mempunyai nilai pendidikan karena isinya menyangkut kronologis dari kegiatan asuhan keperawatan yang dapat dijadikan sebagai referensi pembelajaran bagi peserta didik profesi keperawatan, aspek keuangan semua asuhan 
keperawatan yang belum, sedang atau telah diberikan didokumentasikan yang dapat dijadikan acuan atau pertimbangan biaya bagi klien, aspek penelitian dapat dijadikan sebagai bahan atau objek riset dan pengembangan profesi keperawatan,aspek akreditasi pendokumentasian asuhan keperawatan sebagai indikator dalam penilaian suatu pelayanan keperawatan dalam akreditasi rumah sakit (Nursalam,2007).

Dalam membuat dokumentasi harus memperhatikan aspek-aspek keakuratan data, breafity (ringkas), dan legality (mudah dibaca). Adapun prisip-prinsip dalam melakukan dokumentasi yaitu:

1. Dokumen merupakan suatu bagian integral dari pemberian asuhan keperawatan.

2. Praktik dokumentasi bersifat konsisten.

3. Tersedianya format dalam praktik dokumentasi.

4. Dokumentasi hanya dibuat oleh orang yang melakukan tindakan atau mengobservasi langsung klien.

5. Dokumentasi harus dibuat sesegera mungkin.

6. Catatan harus dibuat secara kronologis.
7. Penulisan singkatan harus menggunakan istilah yang sudah berlaku umum dan seragam.

8. Tuliskan tanggal, jam, tanda tangan, dan inisial penulis.

9. Catatan harus akurat, benar, komplit, jelas, ringkas, dapat dibaca, dan ditulis dengan tinta.

10. Dokumentasi adalah rahasia dan harus disimpan dengan benar.

Dokumentasi keperawatan dapat menjadi alat bukti hukum yang sangat penting, kebiasaan membuat dokumentasi yang baik tidak hanya mencerminkan kualitas mutu keperawatan tetapi juga membuktikan pertanggunggugatan setiap anggota tim keperawatan dalam memberikan asuhan keperawatan. Beberapa aturan pencatatan yang perlu diikuti agar dokumentasi keperawatan yang dibuat sesuai dengan standar hukum diantaranya:

1. Dokumentasi keperawatan yang dibuat memenuhi dan memahami dasar hukum terhadap kemungkinan tuntutan malpraktek keperawatan.

2. Catatan keperawatan memberikan informasi kondisi pasien secara tepat meliputi proses keperawatan yang diberikan, evaluasi berkala dan mencerminkan 
kewaspadaan terhadap perburukan keadaan klien.

3. Memiliki catatan singkat komunikasi perawat dengan dokter dan intervensi perawatan yang telah dilakukan.

4. Memperhatikan fakta-fakta secara tepat dan akurat mengenai penerapan proses keperawatan. Data tersebut mencakup anamnesis kesehatan, pengkajian data, diagnosis keperawatan, menentukan tujuan dan kriteria hasil, membuat rencana tindakan keparawatan, melaksanakan tindakan keperawatan, mengevaluasi hasil tindakan keperawatan, membubuhkan tanda tangan dan nama terang perawat yang melaksanakan, membuat catatan keperawatan, membuat resume keperawatan serta catatan pulang atau meninggal dunia.

5. Selalu memperhatikan situasi perawatan pasien dan mencatat secara rinci masalah kesehatan pasien terutama pada pasien yang memiliki masalah yang kompleks atau penyakit yang serius.

Model dokumentasi keperawatan yang tepat dan efektif ialah sebagai berikut:

\section{* Dokumentasi Pengkajian Asuhan}

\section{Keperawatan}

Pengkajian adalah tahap awal dari proses keperawatan dan merupakan proses suatu pengumpulan data yang sistematis dari berbagai sumber untuk mengevaluasi dan mengidentifikasi status kesehatan klien (Lyer et al,1996).

Menurut Nursalam (2011), kriteria pengkajian keperawatan meliputi :

1. Pengumpulan data

a. Tipe data

Tipe data pada pengkajian keperawatan terdiri dari data subjektif dan data objektif.

Data subjektif adalah data yang didapatkan dari klien /pasien sebagai suatu pendapat terhadap suatu situasi dan kejadian, data objektif adalah data yang diobservasi dan diukur oleh perawat.

b. Fokus pengambilan data

Fokus pengambilan data meliputi riwayat status kesehatan sebelumnya dan saat ini, pola koping yang pernah digunakan dan yang saat ini digunakan, fungsi, status sebelumnya dan saat ini, respon terhadap terapi medis dan intervensi keperawatan, resiko untuk masalah potensial hal-hal yang dapat menjadi dorongan atau kekuatan bagi klien.

\section{Karakteristik Data}

Data yang dikumpulkan untuk menunjang diagnosa keperawatan harus mempunyai 
karakteristik yang lengkap, akurat, nyata dan relevan.

\section{Sumber Data}

Data-data yang dikumpulkan dapat diperoleh tidak hanya dari klien tetapi dari orang terdekat (keluarga), catatan klien, riwayat penyakit terdahulu, konsultasi dengan terapi, hasil pemeriksaan diagnostik, catatan medis, dan sumber kepustakaan.

\section{* Dokumentasi}

Diagnosa

\section{Keperawatan}

Diagnosa asuhan keperawatan adalah pernyataan yang menjelaskan status atau masalah kesehatan aktual atau potensial serta penyebabnya (Nursalam,2007).Tahap diagnosa adalah tahap pengambilan keputusan pada proses keperawatan yang meliputi identifikasi apakah maslah klien dapt dihilangkan, dikurangi atau diubah melalui tindakan keperawatan (Nursalam,2007).Kriteria proses keperawatan meliputi : proses diagnosa terdiri dari atas analisis, interprestasi data, identifikasi masalah, klien dan perumusan diagnosis keperawatan, diagnosa keperawatan terdiri dari atas masalah, penyebab, dan tanda atau gejala, atau terdiri atas masalah dan penyebab, bekerjasama dengan klien, petugas kesehatan lain untuk memvalidasi diagnosa keperawatan, melakukan pengkajian ulang, dan merevisi diagnosa berdasarkan data terbaru (Nursalam2007).Tujuan diagnosa keperawatan dalam asuhan keperawatan untuk mengidentifikasi masalah adanya respon klien terhadap status kesehatan, faktor yang menunjang atau menyebabkan suatu masalah, kemampuan pasien untuk mencegah atau menyelesaikan masalah, mengkomunikasikan masalah klien pada tim kesehatan, mendokumentasikan tanggung jawab dalam identifikasi masalah, mengidentifikasi masalah utama perkembangan

keperawatan

(Nursalam,2007).

\section{Dokumentasi}

Rencana Keperawatan

Tujuan perencanaan intervensi keperawatan dan aktivitas keperawatan untuk mengurangi, menghilangkan, dan mencegah masalah keperawatan klien. Kriteria proses perawatan membuat rencana tindakan asuhan keperawatan untuk mengatasi masalah dan meningkatkan kesehatan meliputi perencanaan terdiri atas prioritas, tujuan dan rencana tindakan keperawatan, bekerjasama dengan klien dalam menyusun rencana tindakan keperawatan, perencanaan bersifat 
individual sesuai dengan kondisi atau kebutuhan klien, mendokumentasikan rencana keperawatan (Nursalam,2007).

Tujuan rencana asuhan keperawatan yaitu tujuan administrasi meliputi mengidentifikasi fokus keperawatan individu atau keluarga, membedakan tanggung jawab perawat dengan profesi kesehatan lainnya, menyusun kriteria guna pengulangan asuhan keperawatan dan evaluasi, keberhasilan asuhan keperawatan, menyediakan kriteria klasifikasi klien, sedangkan tujuan klinik meliputi suatu pedoman dalam penulisan, mengkomunikasikan asuhan keperawatan yang akan diimplememtasikan dengan perawat lain seperti apa yang akan diajarkan, apa yang harus diobservasi, apa yang akan dilakukan. Menyusun kriteria hasil (outcome) guna pengulangan asuhan keperawatan dan evaluasi keberhasilan asuhan keperawatan, rencana intervensi yang spesifik dan langsung bagi perawat untuk melaksanakan intervensi kepada klien dan keluarganya .

\section{* Dokumentasi}

Implementasi

\section{Keperawatan}

Implementasi adalah pelaksanaan dari rencana intervensi untuk mencapai tujuan yang spesifik yaitu membantu klien dalam mencapai tujuan yang telah ditetapkan mencakup peningkatan kesehatan, pencegahan penyakit, pemulihan kesehatan dan mempasilitasi koping (Lyer et al,1999).Kriteria pengimplementasian tindakan yang telah diidentifikasi dalam rencana asuhan keperawatan meliputi bekerjasama dengan klien dalam pelaksanaan tindakan keperawatan, kolaborasi dengan tim kesehatan lain, melekukan tindakan keperawatan untuk mengatasi kesehatan klien, memberikan pendidikan pada klien dan keluarga mengenai konsep ketrampilan asuhan diri serta membantu klien memodifikasi lengkunganyang digunakan, mengkaji ulang dan merevisi pelaksanaan tidakan keperawatan berdasarkan respon klien (Nursalam 2007).

- Dokumentasi

Evaluasi

\section{Keperawatan}

Evaluasi asuhan keperawatan merupakan fase akhir dari proses keperawatan. Hal-hal yang dievaluasikan adalah keakuratan, kelengkapan, kualitas data, teratasi atau tidaknya masalah klien, dan pencapaian tujuan serta ketepatan intervensi keperawatan (Nursalam,2007).Kriteria perawat mengevaluasi kemajuan klien terhadap tindakan keperawatan dalam pencapaian tujuan, dan merevisi data dasar dan perencanaan meliputi menyusun perencanaan evaluasi hasil dari intervensi secara 
komprehensif, tepat waktu dan terus menerus, menggunakan data dasar dan respon klien dalam mengukur perkembangan kearah pencapaian tujuan, memvalidasi dan menganalisis data baru dengan teman sejawat, bekerjasama dengan klien, keluarga untuk memodifikasi rencana asuhan keperawatan, mendokumentasikan hasil evaluasi dan memodifikasikan perencanaan (Nursalam,2007).Ada dua macam evaluasi yaitu evaluasi formatif, evaluasi yang merupakan hasil observasi dan analisa perawat terhadap respon klien segera pada saat dan setelah intervensi keperawatan dilaksanakan dimana evaluasi ini dapat dilakukan secara spontan dan memberi kesan apa yan terjadi pada saat itu. Evaluasi somatif, yaitu evaluasi yang merupakan rekapitulasi dan kesimpulan dari observasi dan analisis status kesehatan klien sesuai dengan kerangka waktu yang ditetapkan pada tujuan keperawatan (Nursalam,2007).

Keberhasilan pendokumentasian asuhan kepera-watan sangat dipengaruhi oleh seorang perawat sebagai ujung tombak dalam memberikan asuhan keperawatan (Potter \& Perry, 2005). Menurut Gibson (1996) dalam Suratun (2008) bahwa faktor individu yang memengaruhi perilaku kerja antara lain umur, lama kerja, pendidikan, dan pelatihan. Produktivitas seorang pekerja menurun dengan bertambahnya umur, sedangkan lama kerja mempunyai hubungan yang positif terhadap produktivitas pekerjaan. Siagian (2002) menyatakan bahwa makin tinggi tingkat pendidikan seseorang makin besar keinginan untuk memanfaatkan pengetahuan dan keterampilan. Pelatihan merupakan bagian dari proses pendidikan untuk meningkatkan pengetahuan dan keterampilan (Notoatmodjo, 2003). Dokumentasi dibutuhkan untuk keamanan pasien dan menjaga catatannya untuk tetap jelas, akurat, dan komprehensif menjadi bermanfaat bagi perawat dalam pekerjaan sehari-hari (Bjorvell, 2002 \& Owen, 2005). Hal ini didukung pula oleh pendapat Wang, Hailey, dan $\mathrm{Yu}$ (2011) yang menyatakan bahwa kualitas dokumentasi keperawatan menunjukkan pemberian perawatan yang baik melalui komunikasi yang efektif di antara perawat dan dengan pemberi perawatan yang lain seperti keluarga pasien. Bjorvell (2002) menyatakan dari hasil FGD perawat bahwa cara menuliskan dokumentasi keperawatan membuat mereka menjadi berpikir kritis dan berpikir dengan cara yang berbeda terkait pelayanan yang diberikan kepada pasiennya. 


\section{Penutup}

Asuhan keperawatan merupakan suatu proses keperawatan yaitu suatu metode sistematis dan ilmiah yang digunakan perawat untuk memenuhi kebutuhan klien dalam mencapai atau mempertahankan keadaan biologis, psikologis, sosial dan spiritual yang optimal melalui tahapan pengkajian keperawatan, indentifikasi diagnosa keperawatan, penentuan perencanaan keperawatan, melaksanakan tindakan keperawatan serta mengevaluasinya.Untuk menjamin keamanan petugas dan keselamatan klien, maka seharusnya setiap tahapan dari proses yang dilaksanakan didokumentasikan dengan lengkap, sehingga "apa yang direncanakan dilaksanakan, apa yang di tulis dikerjakan dan apa yang dikerjakan ditulis". Hal ini berhubungan dengan adanya proses analisis konsep dokumentasi keperawatan sebagai standar penting dalam pelayanan kesehatan berkualitas untuk mengevalusi setiap faktorfaktor yang menjadi penghalang bagi perawat dalam melakukan tindakan dokumentasi yang tepat dan menjadi konsep pemodelan dokumentasi yang tepat bagi perawat.Perawat juga dituntut untuk lebih cermat dan berpikir kritis dalam melakukan setiap tindakan asuhan keperawatan.

\section{Daftar Pustaka}

Gustianaa,R.et.al.(2015).

Faktor-Faktor Yang Berhubungan

Dengan Kelengkapan Dokumentasi

Keperawatan.Jurnal Keperawatan

Indonesia.18(1).2-5

Handiyani,H.\&Tarigan,S.(2019).

Manfaat Implementasi Dokumentasi

Asuhan Keperawatan Berbasis

Komputerisasi Dalam Meningkatkan

Mutu Asuhan Keperawatan. Jurnal

Ilmiah

Kesehatan

Pencerah.8(2).112-113.

Mangole,J.E.(2015).

Hubungan Perilaku Perawat Dengan

Pendokumentasian Asuhan

Keperawatan Di Cardiovaskular And

Brain Center Rsup Prof. Dr. R. D.

Kandou Manado. E-journal

Keperawatan.3(2).2-6.

Muryani,P.(2019).

Kualitas Pendokumentasian Asuhan

Keperawatan Di Ruang Rawat Inap

(Studi Di Rsud Kalimantan Tengah).Jurnal Nerspedia.2(1).30-31 
Pramithasari., \& Diah, I. (2016).

Gambaran kinerja perawat dalam mendokumentasikan asuhan keperawatan berbasis komputer.

Jurnal

Keperawatan

Muhammadiyah, $1(1)$ Retrieved from journal.umsurabaya.ac.id

Retyaningsih ,I.Y dan Edi W.B.(2013)

Hubungan Karakteristik Perawat, Motivasi, dan Supervisi,Dengan Kualitas Dokumentasi Proses Asuhan Keperawatan, Jurnal Manajemen Keperawatan.1(2) 107-114.

Rosmalia,D.(2014).

Analisis Sistim Manajemen

Dokumentasi Keperawatan pada

Poliklinik Gigi Rumah Sakit di Bukittinggi. Jurnal Kesehatan Andalas.3(1).968-970

Simamora, R. (2009).

Dokumentasi Proses Keperawatan.

Simamora, R. H., Purba, J. M., Bukit, E. K., \& Nurbaiti, N. (2019). Penguatan Peran Perawat Dalam Pelaksanaan
Asuhan Keperawatan Melalui

Pelatihan Layanan Prima. JPPM (Jurnal Pengabdian Dan Pemberdayaan Masyarakat), 3(1), 25-31.

Sugiyanti,S.(2015).

Hubungan Pengetahuan Perawat

Dalam Dokumentasi Keperawatan Dengan Pelaksanaannya Di Rawat Inap Rsi Kendal.Jurnal Keperawatan.8(2).4-5

Wulandari,D.F. \& Handiyani,H.(2019).

Pengembangan Dokumentasi

Keperawatan Berbasis Elektronik Di Rs X Kota Depok Dengan Menggunakan Teori Perubahan Lewins .Jurnal Keperawatan Global.4(1).57-6

Yuni,S.et.al(2015). Analisis.. dan Perancangan Sistem Informasi Rawat Inap (Studi Kasus : Rumah Sakit Ibu dan Anak Buah Hati Ciputat). Jurnal Sistem Informasi.8(2).2-7 
